\title{
ROLE OF METROPOLISATION IN THE FORMATION OF THE GLOBALIZED REGIONS
}

\author{
SVITLANA PYSARENKO \\ Ivan Franko Nation University of Lviv \\ Universytetska 1, 79000 Lviv, Ukraine \\ e-mail: prosvetka@mail.ru
}

\begin{abstract}
The metropolisation is a morphological version of urbanization and is characterized by the concentration of the different kinds of activity and population in the centres of the country and the growth of the share of population of metropolis agglomeration in the country population. The basis of metropolisation processes and the level of its development are determined by the rank of city and by the corresponding underlying processes of urbanization. The aim of the article is to describe existing processes of metropolization in order to refer them to the situation in Ukraine.

Key words: metropolisation, region, urbanization, global cities, Global Gates
\end{abstract}

\section{INTRODUCTION}

The role of the regions of different sizes grows in the age of economic globalization. The importance of territory as essential and sovereign subject of social development and foreign trade activities of the world countries amplifies. The national economy represents a system of regional economies, most of which exist and develop on the basis of metropolisation processes. The highest metropolisation in the age of globalization is connected with the development of global cities, in particular the Global Gates - the centres of business activity of the world.

The aim of the article is to describe existing processes of metropolisation in order to refer them to the situation in Ukraine. 


\section{THE ESSENCE AND MEANING OF METROPOLISATION}

The metropolisation is a morphological version of urbanization and is characterized by: - the concentration of the different kinds of activity and population in the centres of the country-metropolises, in most cases, in its capital;

- the growth of the share of population of metropolis agglomeration in the country population.

The metropolisation has close connections with the urbanization, which determines the economic growth of regions. The evidence of this is the sharp growth of the economic activity of urban population which is directly connected to the expansion in the number of workplaces in cities.

The basis of metropolisation processes and the level of its development are determined by the rank of city and by the corresponding underlying processes of urbanization.

The metropolises are the centres of spatial economic regions formations as metro-centralized spatial economic territories. The economic territory, according to definition of the Bureau of Economic Analysis (USA), consists of different economic components and is a basic functional unit of the state. Each territory, which contains one or more city centres with adjoining districts, heterogeneous industrial groups, the local and export-oriented industry, actually represents a metropolis.

Metropolises make the base of national economy, the source of new ideas, technologies and innovations. They are generators, engines, stimulators of economic growth. The processes of innovations diffusion play especially important role.

The centres of metropolisation economic spatial systems could be represented by multipurpose cities, as well as cities with the sufficient concentration of business, administrative, entrepreneurial, industrial, infrastructural, trading, financial, innovative activities.

Every metropolized spatial economic region is an open system, which has close interrelation with other similar regions. The national economy is an open system as well. Through the globalized spatial economic regions it is connected to other national economies. In such a way the metropolized spatial economic region becomes globalized and takes a proper place in global economic system.

In complex regions there exists different levels of metropolisation: global, continental, national and regional. The level of globalized region depends on the degree of its participation in the international division of labour. If this participation is insignificant, the regional centre becomes "Gate" / "Quasigate" only in its own country. If the participation is essential, it becomes "Gate" / "Quasigate" on the continental or global levels (Abbott 1996, p. 38).

According to the United Nations data, along with the steady growth of the absolute number of cities, the increasing quantity of world population is accumulated in the big megacities. In the middle of XX cities-millionaires were in each seventh country of the world, in XXI-in every third. In 2008459 agglomerations with 
the population more than one million people have been formed. Approximately $40 \%$ of city dwellers and $20 \%$ of the whole world population live there (Figure 1).

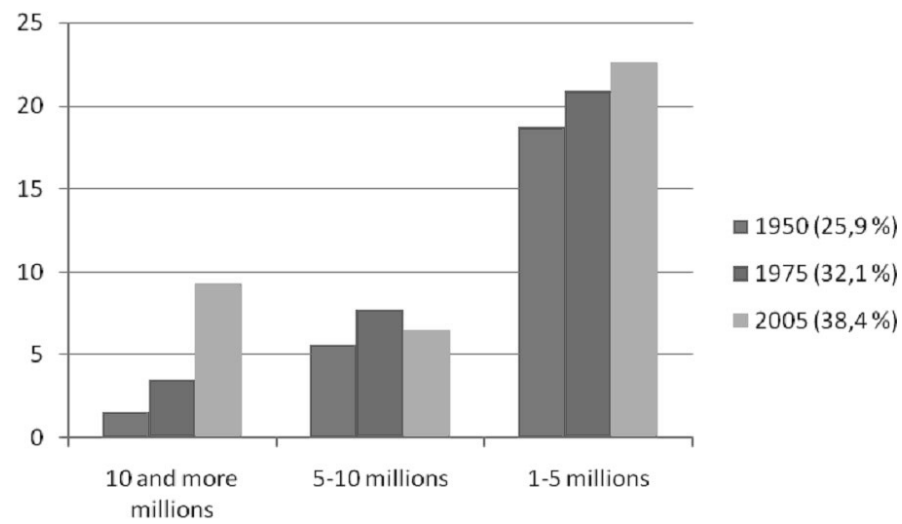

Figure 1 . The share $(\%)$ of city agglomerations with over 1 million people in the aggregate number of urban population, 1950-2005

Source: World Urbanization Prospects: The 2007 Revision (2008).

\section{FORMING THE CENTRES OF WORLD BUSINESS ACTIVITY-THE GLOBAL GATES}

The forming of global city-the Global Gates, the centres of world business activity-is the highest degree of metropolisation development in the age of globalization. These are the agglomerations provided with enormous financial, administrative, information and political functions. They become the main centres of the international business activity. Global cities are connected in the uniform network of the world geopolitical centres. They are one of the major characteristics of globalization. The global city, according to Sassen (2000), is a post-industrial centre integrated into economic as much as possible which develops on the basis of interaction with global city networks.

Among ten top global centres seven are agglomerations with the population above 7 million people. The Big Tokyo heads the list of thirty greatest agglomerations of the world. And, more than half $(51,8 \%)$ cumulative increase in population of global megacities for last 15 years falls into five agglomerations-Tokyo, Mexico, Sao Paolo, Singapore and Siangan (Hong Kong). The population decreases in such cities of Europe, as Amsterdam, Berlin, Copenhagen, Milan, Munich, Prague, Rome, and Asia as Seoul and Taipei (King 1990, p. 192).

For last decades there is traced the substantial reduction in population increase at the leading global centres. Thus, in 1950-1970 the population of the greatest twenty global cities has increased by 51,4 million person, in 1970-1990-by 41,7 million, in 1990-2005-only by 24,9 million person. 
The term "Global City" has appeared in 1990th years in the work of Sassen (2000), professor of sociology at Chicago University. She has formulated seven hypotheses that explain the reasons for such cities emerging.

First, the deepening of the international division of labour coming from the activity of leading transnational corporations has strengthened the significance of cities where the main strategic functions of management, coordination, service, financing are concentrated. The intensive information streams pass through the cities. Their concentration makes cities similar to information centres, and being in city might be compared with the presence in an intensive and dense information stream.

Second, these functions become so complex, that control centres of global manufacturers transfer some of them to specialized service companies ("utsourcing"). The companies more often buy ready services providing accounting, public relations, programming, telecommunications and other functions.

Thirdly, the specialized service companies involved in most complex global markets tend to accommodate in the greatest city centres, using the effects of agglomeration. The complexity of provided services, their ambiguous markets, and the growing significance of transactions speed give the new pulse to city agglomerations development.

Fourthly, the more functions are transferred by the company headquarters to outsourcing, the easier choice of headquarters location is. It explains the advantages and decisive importance of the global cities for service development.

Fifthly, the specialized service companies should offer global services that in turn provide for the global branch network and for the necessity of transnational serving systems. Economic development of these cities breaks ever more away from their hinterlands and even national economies as a whole. It might be considered as one of the initial stages of transnational urban systems that will make the greatest business centres very important in economic development.

The sixth hypothesis consists that the high concentration of the qualified professionals and the profitable service companies in the greatest cities of the countries leads to the escalation of territorial, social and economic inequality. The strategic role of the specialized services results in the increasing number of leading professionals with permanently growing salaries. The constant intensification of the work of the highly skilled personnel resulting in fast and steady growth of their rewards is necessary for the achievement of expected results. Absolutely opposite dynamics for the payment of those workers who do not belong to this category of professionals is observed.

The seventh hypothesis provides that growth of other kinds of economic activities demanded in global cities will be observed, but the level of their profitableness will not allow competing with the highly profitable companies, which take positions of leaders.

The concept of global city is directly connected to the concept of network economy. The industries that rush to concentrate in global cities (the finance and the spe- 
cialized services, multimedia sector, telecommunication services) need to form the transnational networks and to deepen the division of labour in these networks. This process is more powerful than the international competition.

The network-based interactions between global cities are typical not only for economic, but also-increasingly_for political, cultural, social, criminal interrelations. The global cities all over the world are areas where complex processes of globalization get concrete, located forms.

\section{ZONES OF GLOBAL CITIES IN ECONOMIC}

In the age of globalization three main zones of global cities concentration are formed: West-European, North American and Asian-Pacific, each of which has its own specificity. For other regions of the world the category of global cities is presented by only individual centres: Sao Paolo, Rio de Janeiro and Buenos Aires-in South America, Johannesburg — in Africa, Sydney—in Australia and some other.

The main feature of the West-European zone of global cities is the longest history of urban development when these cities have been forming as leaders of regional and global economy. The capital of the Great Britain and France are competing for leadership in the region. The majority of experts prefer nonetheless London that had formed as the global centre in 18-19 centuries. During the long history of development there were created a dense network of global cities of different ranks in the region. In aggregate they form some kind of trans-European "backbone" that stretches from Dublin through London, Paris, cities of a valley of Rhine and Milan and Rome. In 1990th years the second eastern "backbone" started to shape on the territory of the Central Europe.

The North American zone of global cities is much younger, but it is the largest and is deeply integrated in economic system. It's based on complex network of megacities the USA. There are global cities of all ranks. The key positions among them are occupied by New York, Los Angeles and Chicago. They closely cooperate with the global centres of other countries and the regions of the world. Many North American cities have huge potential and will apply for the global status in the future.

The Asian-Pacific zone of global cities is the youngest. It has "linear" character and is formed on an axis "Tokyo-Singapore". This zone is characterized on the one hand by the dominating role of Japanese capital, and on the other by the significant increasing of population and dynamic growth of "minor" global cities-the centres of the new industrial countries, such as Bangkok, Singapore, Siangan (Hong Kong), Taipei, Seoul, Manila and others.

Economic potential of global cities is really tremendous. Ten greatest global cities provide $1 / 10$ gross national products of the world (Figure 2).

The headquarters of the world greatest transnational corporations are located in global cities. According to the list of Global-500, in Tokyo, New York, London and 


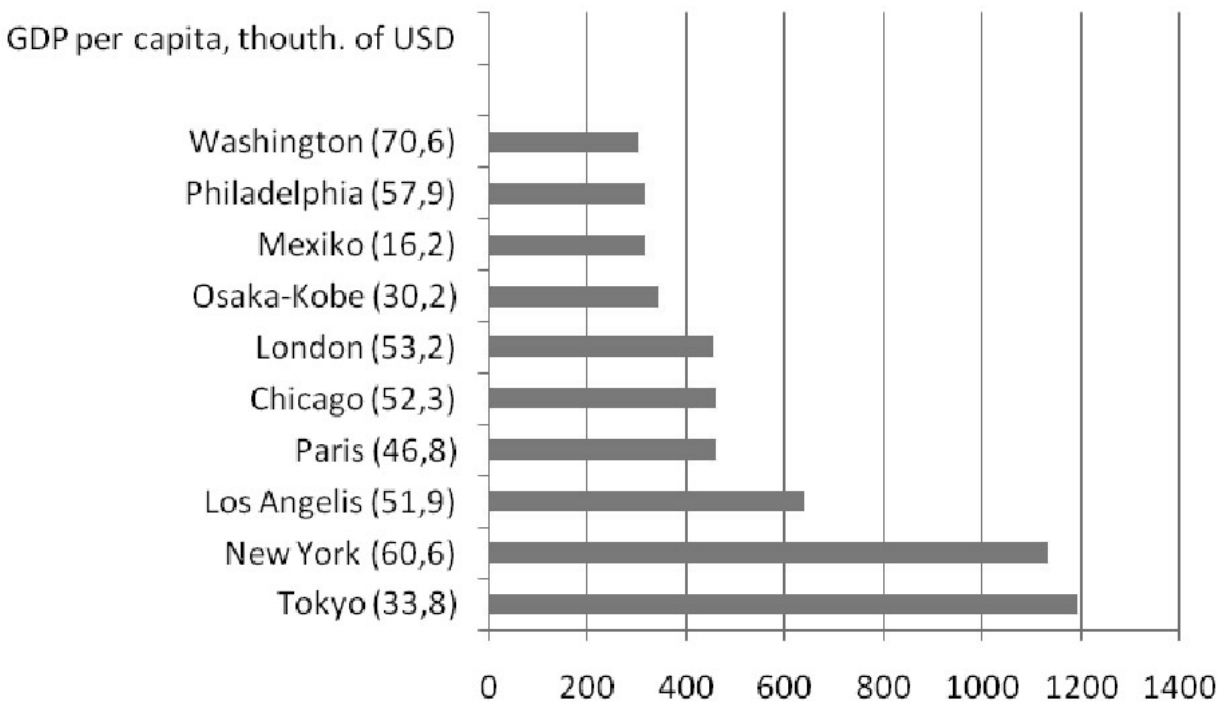

Figure 2. Agglomeration as GDP leaders, 2005 Source: UK Economic Outlook (2007).

Paris there are more than 1/4 transnational corporations headquarters including 500 greatest companies of the world. Tokyo heads the list; there are 56 transnational corporations' headquarters from among 500 greatest non-financial corporations of the world and 9 from 12 greatest industrial-financial groups of the country. That's why some researchers often consider Tokyo to be the leading management centre of the global industry.

During last ten years such cities, as Beijing, Singapore, Shanghai, Siangan (Hong Kong), Sao Paolo etc have the increasing importance for the location of the headquarters of leading non-financial corporations.

The global cities develop as the post-industrial centres. So, in London, New York, Paris, San Francisco, the industry share in the structure of both employed population and gross national product makes less than 6-7\%. Several decades ago the industry share achieved 1/3 and more (Tsygankov P.A. (ed.) 1998, p. 203). This indicates that under condition of new economy forming, the global cities accumulate functions of information producing and distribution. They naturally act as the leading centres of mass communications. There are situated the headquarters of the companies specialized in telecommunication services, information systems and technologies, as well as leading media concerns. The list of world key media-centres includes New York, London, Paris, Los Angeles, Munich, Berlin and Amsterdam. These seven cities accommodate more than $30 \%$ of units of 33 leading global media firms (Tsygankov P.A. (ed.) 1998, p. 123).

The global cities assemble the prevailing share of headquarters of both international intergovernmental organizations (IIO) and groups, and international nongovernmental organizations (INO). By estimation, seven key geopolitical centres- 
New York, Paris, London, Brussels, Geneva, Washington and Vienna-accumulate more all 2/3 IIO headquarters. New York-the location of UN headquarters and its large structural divisions_-holds a specific place (Tsygankov P.A. (ed.) 1998, p. 103).

The important mission of global cities is to afford a base for short-term official, business, scientific, representative, and other visits. Top ten global cities accumulate more than $10 \%$ of all visiting international tourists and absorb the lion's share of the largest sector of business tourism-corporate trips (Tsygankov P.A. (ed.) 1998, p. 103).

Global cities have become the greatest accepting centres for migration streams from all regions of the world. All of them act as the key management centres of the global exchange of human resources. For example, in London the total volume of external and internal migration achieves 710-730 thousand people in a year, i.e. every tenth inhabitant of Great Britain capital is engaged in migration processes.

The revival of global cities as greatest educational and research centres is observed as well. In all global cities, there is a score of high schools and the systems of university centres.

For 2002-2004 the index of scientific citing showed two leaders among the world research centres-Tokyo (more than 80 thousand references) and London (more than 70 thousand references). Other megacities, including Paris and New York, lagged behind them considerably. Beijing was inside the top ten research centres according to the citing rating (more than 40 thousand references) (Figure 3).

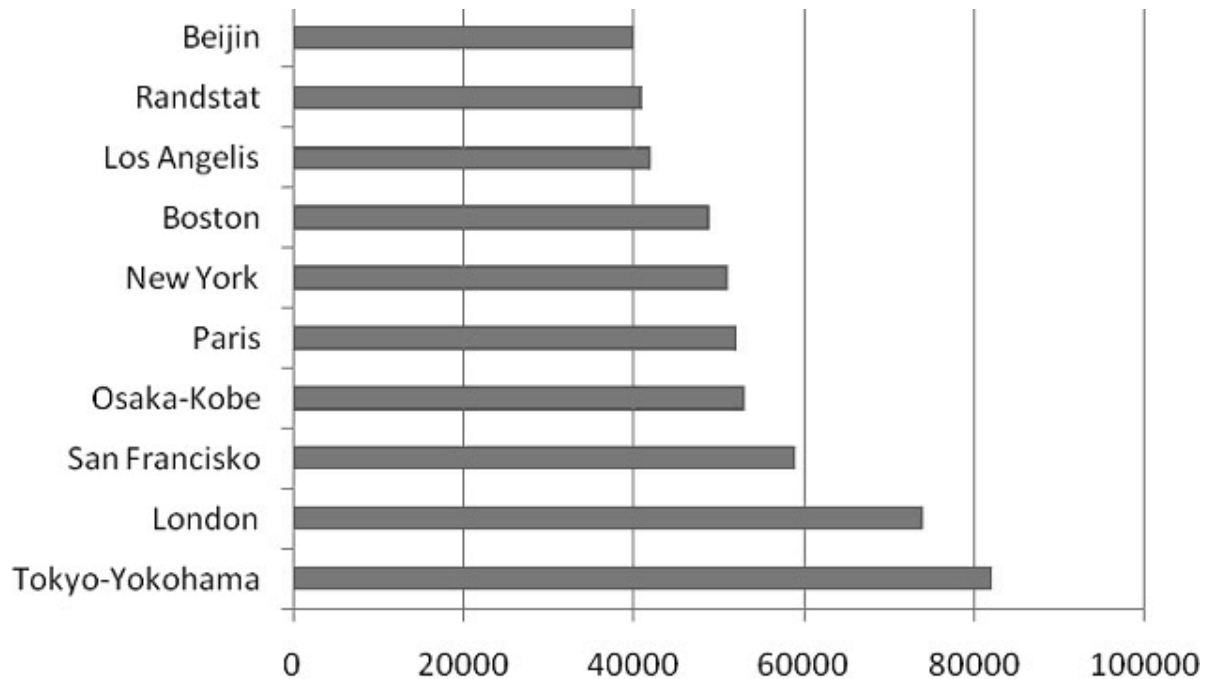

Figure 3 The greatest research centres of the world, 2002-2004

Source: Matthissen C.SW., Schwarz A.W., Find S. (2006).

There are a lot of classifications and ranging of global cities. Empirically proved, interesting and modern classification is offered by scientists from British Loughborough University Globalization and World Cities Study Group-GAWC. Their rang- 
ing is based on the numerical score of city's activity in the four types of services: business accounting and audit, advertising, finance and banks, insurance.

Depending on the score all cities are divided into fours ranks and 12 categories (12-the highest, 1 -the lowest). The analysis distinguishes 55 global cities of a different rank; four of them-London, New York, Paris, Tokyo-receive the highest point. They are the leading global centres of the world, the major elements of world system, the main generators of globalization process, the centres of the international cooperation and competitions, although they have different age; historic, geographical, demographic, social and economic conditions of formation, dynamics of development, specialization, place in the international division of labour, and represent different civilization regions of the world.

\section{ROLE OF METROPOLISATION IN THE DEVELOPMENT OF NATIONAL ECONOMY IN UKRAINE}

The formation of the globalized regions in Ukraine is directly connected to the metropolisation processes in the greatest cities, and also, the expansion of regions internationalization. The calculated indexes of regions globalization testify that the Kiev region and Ukrainian industrial regions are the most globalized in the country. In those regions the metropolisation processes are observed in such big cities, as Kiev, Kharkiv, Donetsk, Odessa, Dnipropetrovs'k, and Zaporizhya. In comparison with other regions they have a hyper high degree of internationalization (the export share in a total regional product reaches 87.0-99.0\%).

The strategically important transport directions pass through Ukraine; they connect it to the Central, East, Southern, Northern Europe, the Middle and Far East, and Africa. In 1999 British Institute Randel has conferred to Ukraine the highest index of transitivity.

This entitles to consider Ukraine as "Gate" of continental scale. It renders such international services, as transport, culture and recreation, information. The largest share in the system of the international services provided by Ukraine has transport services. They cover two kinds of activity-transit transportations and dispatcher services.

Among Ukrainian cities-millionaires capital Kiev has a special place. According to existing classification, Kiev is one of 67 cities of the world, which have sufficient potential to obtain the global status in the future.

In consideration of the scientific potential Kiev takes leading place among the greatest science centres of Europe and world. There is situated the National Academy of Sciences of Ukraine and the majority of its institutes; a lot of them have the world famous scientific schools. In the city there is concentrated $30 \%$ of Ukrainian scientific potential: $216(31.7 \%)$ research and 48 (16.5\%) engineering organizations, as well as 18 universities and 49 high schools. 
The scientific institutes of the National Academy of Sciences of Ukraine implement every year over 2000 newest developments into different branches of Ukrainian economy. That is the high technologies including informational; the machines, the equipment, the materials, the automated complexes and systems, the software products, the databases and knowledgebase, the cultivars species, the methodical recommendations and techniques, and the standards.

The cooperation with the International Institute of Applied System Analysis IIASA, the European Organization of Nuclear Researches CERN, European Incoherent Scatter Scientific Association EISCAT, etc takes place.

Kiev is the greatest financial centre of Ukraine, where $80 \%$ of the banking capital of the country and its stock exchanges concentrate. Thus, Kiev has potentials, which will allow it becoming a financial-innovative centre of the world.

\section{REFERENCES}

Abbott, C . (1996), The internationalization of Washington, D.C., Urban Affairs Review, 31, 5 .

King, A. (1990), Global cities: post-imperialism and the internationalization of London, London.

Matthissen, C. S. W., Schwarz, A. W. and Find, S. (2006), World cities of knowledge: research strength, networks and nodality, Journal of Knowledge Management, 10, 5.

Sassen, S. (2000), Territory and territoriality in the global economy, International Sociology, 15, 2, 372-393.

UK Economic Outlook, 2007, Pricewaterhous Coopers.

Vyzoye nyeznaniyu: tyeoriya myezhdunarodnykh otnoshyeniy pyeryed litsom budushchyego, (1998), in: Tsygankov, P. A. (ed.) Myezhdunarodnyye otnoshyeniya: sotsiologichyeskiye podkhody.

World Urbanization Prospects: The 2007 Revision, 2007, 2008, New York. 
http://rcin.org.pl 